\title{
Becoming a Principal: Access Factors for Females
}

\author{
Rae Ann Kruse \\ Northern Oklahoma College \\ Bernita L. Krumm \\ Oklahoma State University
}

Guided by Standpoint Theory, researchers conducted this case study to identify factors influencing access to Oklahoma's secondary school principalship for four female first-time principals. Regardless of equity legislation and increasing numbers of females with advanced degrees, the numbers of men and women who hold secondary school administration positions continue to be disproportionate to their numbers in the teaching profession. Three standpoints emerged: In the transition from teacher to administrator, each participant was nurtured by another individual; male sponsors were their primary encouragers; and participants had strong emotional investments in the schools and communities of their employment. Aspiring female principals should cultivate strong support systems, seek out mentors, and strengthen their professional networks. Accepting stepping-stone administrative positions may be an essential starting point for aspiring female secondary principals; administrative skills can be gained through internships, assistant principal positions, and administrative positions in lower grade levels.

\section{Keywords: secondary principals, women principals, school leadership, gender and leadership}

In October 2009, President Obama signed legislation that increased federal grant money and was designed to stimulate the economy, bring equity into the workforce, and encourage single mothers to return to college. Ironically, from 2000 to 2009, women already outnumbered men in college enrollment; beginning in May 2005, women outnumbered men in every post-secondary degree category: associate, bachelor, master, doctoral, and professional (Marklein, 2005). Women exceeded men in earning bachelor's and master's degrees and earned two-thirds of all doctorates in education in the 2007-2008 school year (Sommers, 2008). A 2009 National Science Foundation (NSF) survey reported women earned $57 \%$ of bachelor's degrees and $59 \%$ of master's degrees. The NSF survey also identified 2006 as the fifth consecutive year that women earned the majority of research Ph.D. degrees awarded to U.S. citizens. Data from the 2010 Census Bureau data confirmed that among the working population of 25 to 29 -year-olds, $36 \%$ of women held a bachelor's degree or more, compared with $28 \%$ for men (Bernstein, 2011).

Investigating enrollment patterns in school administration over a ten year period at a comprehensive U.S. university, Guramatunhu Mudiwa (2015) found females outnumbered males 2:1. However, despite outnumbering men in educational leadership preparation programs, advanced degrees for women have not translated into more females becoming high school principals. Roser, Brown, and Kelsey (2009) found that female principals in Texas were in the majority at the elementary level (73.5\%), but in the minority at both middle school (41.3\%) and high school (29.8\%) levels. Whether one considers public or private schools, female administrators are accepted and employed at the elementary level but underrepresented at the secondary school level. Women comprise the largest percentage of both the teaching profession and educational leadership preparation programs, but since 1993 have held less than a third of high school principal positions (Digest of Educational Statistics, 2007).

Public perception regarding who is suited to lead schools may impact an individual's advancement. In a Pew Research Center survey, Keiper (2011) reported, "77 percent of [2,142 adult] respondents...said it was necessary for a woman to go to college to get ahead in life, while only 68 percent said the same for men" ("Survey” para. 1). Women appear to be a segment of the population qualified but underutilized to serve as high school principals. Whether intentional or unintentional, sex discrimination may be a major factor for females not becoming administrators.

Other factors include the long work hours, too many personal responsibilities, longer tenure in the classroom before moving into administration, changes in career opportunities, outmoded hiring 
practices, and school politics. According to a study of the American School Superintendency conducted by the American Association of School Administrators (AASA), administrators work an average of 50 hours per week. Younger women with families reported this lifestyle was not appealing (Glass, 2000). Hoff, Menard, and Tuell (2006) reported that 68\% of female administrators waited until their children were grown because of the difficulty in balancing personal life and the extra duties required outside of the school day. Women spend more years as classroom teachers before moving into administration than do their male counterparts; 7-10 years is the norm for women as compared to 5-6 years for men (Hoff \& Mitchell, 2008). Some women find moving into administration for only a few years before retirement not worthwhile.

Data from The National Center for Educational Statistics (2013) and the Digest of Educational
Statistics (2007) in Table 1 show that more women serve as elementary school principals than as high school principals. In 1994, females comprised $41 \%$ of public elementary school principals. This percentage grew to $56 \%$ in the 2004 school year and 64\% by 2012. Private elementary school statistics were even higher, remaining constant at 68\% from 1994 to 2004 with a slight drop to $65 \%$ by 2012 . The percentage of women serving as high school principals is lower than that serving in elementary schools. In 1994, 14\% of public school principals were female. This percentage grew to 26\% by 2004 and 30\% by 2012 . For private high schools, the statistics maintained at $34 \%$ from 1994 to 2004 and increased to $43 \%$ by 2012.

Table 1

Percent of Female Principals by School Level and Type by Year

\begin{tabular}{lllll}
\hline School Level and Type & 1994 & 2000 & 2004 & 2012 \\
\hline Public Elementary Schools & .41 & .52 & .56 & .64 \\
Private Elementary Schools & .68 & .68 & .68 & .65 \\
Public High Schools & .14 & .22 & .26 & .30 \\
Private High Schools & .34 & .34 & .34 & .43 \\
\hline
\end{tabular}

Women seem to have fewer entry points for becoming high school principals, and promotion from elementary principal to the superintendent is rare (Glass, 2000). Glass noted that $65 \%$ of male superintendents previously coached athletics. Research supports the argument that coaching provides the easiest access to the high school principal's position.

\section{Standpoint Theory}

Feminist theory is a sub-area of critical theory that specifically deals with exploitations based on sex and gender. There is not one single defining body of feminist theory, but several theories with common themes. This study used feminist Standpoint theory to view the inequality of differing social groups from the standpoint in which they view the world. Standpoint feminism professes that because women's lives in almost all societies are different than men's, women hold a different type of knowledge. Narayan (1989) recognized that women's location as a subordinated group allows them to see and understand the world in ways that are different from and challenging to the existing male-biased conventional wisdom (pp. 256-272).

The common characteristics of Standpoint theory include the following:

- A standpoint is a place from which to view the world that determines what we focus on as well as what is obscured from us.

- The social groups to which we belong shape what we know and how we communicate.

- Standpoint theorists suggest that societal inequalities generate distinctive accounts of nature and social relationships.

- $\quad$ The perspective from the lives of the less powerful can provide a more objective view than the perspective from the lives of the more powerful.

- Inequalities of different social groups create differences in their standpoints.

- $\quad$ All standpoints are partial. A person can have many standpoints at a time. 
- All the social communities that a person belongs to create their overall standpoint. (Wood, 1993)

Standpoint theory is used by sociologists, political theorists, and communication researchers. Hartsock (1983) stated, "Feminist Marxists and materialist feminists more generally have argued that the position of women is structurally different from that of men, and that the lived realities of women's lives are profoundly different from those of men” (p. 284). Standpoint theory affirms that all individuals or groups do not experience culture in the same way. People who are perceived to belong to groups with more social power have their views validated more than those in marginalized groups. People in marginalized groups must learn to function in many groups or to 'pass' in the dominant culture to survive, even if that group does not exhibit their individual perspective (DeFrancisco, 2007).

In 2001, Harding theorized that the experiences of women can provide a perspective in areas where their viewpoint has been left out. Literature written from the standpoint of patriarchal privilege often does not accurately describe women's paths to employment in administration. Feminist standpoint theory offers a viewpoint for understanding this transition.

\section{Methodology}

Hoff and Mitchell's (2008) research indicated that gender-related factors often deter women from entering school administration roles and impede their progress toward advancement. However, "a qualified talent pool [for school administrators] does exist, and statistics show that this pool consists increasingly of women, who for some time have represented the largest percentage of both the teaching professional and educational leadership preparation programs" (p. 1). The question remains: Why are women underrepresented in school administration?

This study was conducted to identify factors that influence females' access to Oklahoma high school principal positions. The study addressed the commonalities and differences experienced by four females who were first-time principals in public high schools and the techniques they employed to transition from teacher to principal. The research moves the focus from the negative perspective of barriers that keep females from becoming high school principals to positive solutions gained from lived experiences of practicing administrators.

The following research questions guided this study:

1. How do Oklahoma female high school principals describe their experiences of seeking and achieving employment as a principal?

2. What factors affected their advancement into administration?

3. What barriers, if any, limited their transitions from the classroom into administration?

\section{Participants and Context}

Oklahoma schools are divided into seven Class distinctions ranging from the smallest schools (Class B) to the largest (Class 6A). Table 2 indicates the Class designation process. Class size is not based on a set number of pupils, but fluctuates slightly year to year depending upon total school enrollment.

Table 2

Class distinctions

\begin{tabular}{ll}
\hline Class & Size \\
\hline 6A & Largest 32 schools \\
5A & Next largest 32 schools \\
4A & Next largest 64 schools \\
3A & Next largest 64 schools \\
2A, A, B & Divided evenly between 2A, A, and B with the greatest number in Class B, if not evenly divisible by 3. \\
\hline
\end{tabular}

Table 3 shows the number of female principals by Class. Class designations were obtained from the 2011 Oklahoma Secondary Schools Athletic Association website as classified for basketball teams; every school listed on the open records request has a basketball team. Although class designations are not consistent for others sports, school enrollment numbers and Class designations for basketball minimally change from school year to school year. 
Table 3

Number of Female Secondary Principals in Oklahoma per Class

\begin{tabular}{llll}
\hline Class of School & $\begin{array}{l}\text { Number of Schools in the } \\
\text { Class }\end{array}$ & $\begin{array}{l}\text { Number of Female } \\
\text { Principals }\end{array}$ & $\begin{array}{l}\text { Percent of Schools with } \\
\text { Female Principals }\end{array}$ \\
\hline B & 94 & 18 & .19 \\
$\mathrm{~A}$ & 93 & 15 & .16 \\
$2 \mathrm{~A}$ & 93 & 14 & .15 \\
$3 \mathrm{~A}$ & 64 & 14 & .22 \\
$4 \mathrm{~A}$ & 64 & 11 & .17 \\
$5 \mathrm{~A}$ & 32 & 9 & .28 \\
$6 \mathrm{~A}$ & 32 & 10 & .32 \\
\hline Total & 388 & 91 & .23 \\
\hline
\end{tabular}

Additionally, 17 female principals were in charge of alternative schools, homebound programs, schools in juvenile detention centers, or schools specifically for pregnant students or parents. Three of these schools were in $5 \mathrm{~A}$ districts, and 14 were in $6 \mathrm{~A}$ districts. When alternative schools were removed from the equation, $23 \%$ of standard Oklahoma high schools were led by females (91/388). When alternative schools were included in the equation, the percentage of female principals in large schools increased.

\section{Procedures and Data Collection}

The open-records request from the Oklahoma State Department of Education provided a pool of 91 female principals employed in their first high school principal position. This list was cross-referenced with an open-records request from the Oklahoma State Department of Education of 102 females who attended the State Department of Education's required workshop for new high school principalsCriteria for Effective Teaching and Administrative Performance. Participants were first-time high school principals, represented both large and small schools and different areas of the state.

The selected schools were rural and suburban; one school was a Title I school (federally assisted, low-income); another was Title I and Title III (a federally funded supplementary educational services). To maintain confidentiality, pseudonyms were used for the four principals and their high schools.

The primary data sources were individual interviews, conducted over a two month period. Each interview session consisted of three to seven hours - conducting the interview, touring the school, observing classrooms, and meeting the teachers and staff. Participants provided informal demographic data, and an introductory portion of the interview included number of years each participant spent in the classroom, number of years as principal, and school size. The remaining interview questions focused on the positive experiences the principals encountered during their quests to become high school principals. Additional data for the study were researcher field notes and participant observations, documents, and follow-up e-mails.

\section{Data Analysis}

Standpoint Theory guided the analysis of the data. Creswell (2009) described the use of a theoretical perspective in qualitative research as "an overall orienting lens for the study of questions of gender, class, or race (or other issues of marginalized groups)" (p. 62). Standpoint Theory was selected because of its focus on marginalized groups. In Oklahoma, female high school principals are outnumbered by their male counterparts to the extent that they may be considered a marginalized group. Interview transcripts and field notes were entered into a Microsoft Word document. Each administrator's file was assigned a unique font color and data were sorted and grouped by school. Direct quotations from each interview transcript comprised the data in individual cells in the first column of a Microsoft Word table, formatted to be less than 5 inches wide to facilitate transfer to a 3 x 5 index card. Content was examined line by line, and open coding was used to initially conceptualize recurring patterns and themes without any restrictions other than to discover chunks of meaning and "to identify units of information that contribute[d] to themes or patternsthe study's findings" (Bloomberg and Volpe, 2008, p. 98). First impression labels were entered in the second column. Quotations and descriptions were then highlighted and cut into "data strips," and 
transferred to the index cards. The index cards were then shuffled and reorganized using axial coding to identify dominant themes that identified common factors participants experienced during their pursuits of the principalship. Labels were refined as patterns began to develop during axial coding. These themes were then analyzed in relation to Standpoint theory and the research questions.

Additionally, transcripts were analyzed by highlighting hard copies of the transcription documents as well as individually and collectively using the online Word Cloud generator (www.wordle.net). The Word Cloud software is similar to NVivo and looks for most often used words. The Word Clouds did not identify any different patterns, ideas, or relationships from the ones created through axial coding.

\section{Participants}

\section{Demographics}

Sixty-four schools were in Oklahoma schools in Classes 5A-6A; Minnie Richardson and Katie Fitzgerald served schools in this category. Classes 2A-3A-4A held 223 schools and Classes A-B held 191 schools; Aileen Lynes and Ester Wyckham were the respective principals in these categories. The four schools ranged in size from 77 in grades 7-12 to 2,000 students in grades 9-12. The duties for each principal were as varied as the school populations.

All four principals were between the ages of 50 and 60. The principals taught from 12 to 19 years in the classroom before moving into administration and had been high school principals from 1 to 10 years. Table 4 lists the demographic information provided by participants.

Table 4

Participants’ Demographic Information

\begin{tabular}{lllc}
\hline Participant (Pseudonym) & $\begin{array}{c}\text { Years as } \\
\text { Teacher }\end{array}$ & Subjects Taught & Grade Level \\
\hline Dr. Minnie Richardson & 14 & English & $\begin{array}{c}\text { High school and } \\
\text { middle school }\end{array}$ \\
Mrs. Aileen Lynes & 17 & Business & $\begin{array}{c}\text { Career Tech } 11^{\text {th }}, 12^{\text {th }} \\
\text { and Adults }\end{array}$ \\
Mrs. Ester Wyckham & 12 & $\begin{array}{c}\text { Kindergarten, English, } \\
\text { Reading Specialist }\end{array}$ & $\begin{array}{c}\text { Elementary and } \\
\text { high school }\end{array}$ \\
Mrs. Katie Fitzgerald & 19 & $\begin{array}{c}\text { Biology, science, } \\
\text { physical science }\end{array}$ & High school \\
\hline
\end{tabular}

Overall, the four principals shared several factors. All four were encouraged to step out of the classroom and into administration; all reported having strong mentors and support systems. None had gained leadership experience through coaching athletic teams. Two reported barriers their first year as assistants to female principals; self-imposed barriers were also a common factor.

\section{Case 1: Dr. Minnie Richardson, Johnson}

High School. Principal Richardson of Johnson High School is a suburban high school with over 2,000 students in grades 9-12 and four assistant principals, one assigned to each of the four grades. The two female and two male assistant principals work with 125 teachers and 35 support staff employed at the school. Dr. Richardson, a petite 60-year-old woman, greeted me wearing dark grey pants, a striped oxford shirt, low-heeled boots, and stylish gold jewelry that complemented her glasses. She carried the walkie talkie that accompanied her any time she left her office.

Dr. Richardson earned her bachelor of arts from a university in the town of her current employment, a master's degree in education from an out-of-state university, and a doctorate in higher education from an Oklahoma university. Her administrative experience was all within one school district. Before her six years as principal at Johnson High School, she was a middle school assistant principal for four years, a middle school principal for three years, and an assistant principal at her high school for two years.

Dr. Richardson said she was an Air Force "trailing spouse" who taught in Arizona, Louisiana, Ohio, Washington, D.C., California, and Oklahoma. She grew up in a neighboring suburb of her current employment, and her parents never left the area. When her mother encouraged her to get her doctorate, Dr. Richardson told her, "Mom, there is no 
reason for a teacher to have a doctorate. I would be too expensive. I move around too much.”

In addition to her mother's encouragement, Dr. Richardson also received professional advice early in her career from a California principal. He increased her level of responsibility as a teacher and casually talked about the business of education. She said he encouraged her to participate in professional development, and she attended everything within driving distance. This mentor also nominated Dr. Richardson to be on the accreditation team to go on school visits. She explained, "I was already in my administrative classes, so I got to see [the schools] through a quasi-administrative role.”

Dr. Richardson was a pleasant blend of corporate CEO and doting mother. When an elderly gentleman seated next to her at a school choir performance asked, "Which one is yours?" she replied, "They're all mine! I'm their principal.”

\section{Case 2: Mrs. Aileen Lynes, Huyck High}

School. Mrs. Lynes, a tall and statuesque 49-yearold with thin, chin-length light brown hair and stylish, skinny glasses. She wore black pants, a silk blouse and an unbuttoned jacket with a tapestrydesigned fabric; her jewelry consisted of a long necklace and wedding ring. Mrs. Lynes’ physical stature was reminiscent of Oklahoma pioneer women. She appeared as though she would be as comfortable working on her family's farm as in the principals' office. Her demeanor was organized, professional, and efficient.

Mrs. Lynes earned bachelor's and master's degrees from nearby universities. She was the mother of two sons: one was attending the state university; the other was in the military. Her husband was employed for a major corporation with a work area that encompassed multiple surrounding states; she indicated he was on the road more than he was at home.

Mrs. Lynes had the strongest connection to her community of any of the study participants. She revealed,

My grandmother graduated from Huyck, my dad graduated in 1958, I did, and both my boys, so it was my home. It was my home school, and I really think that is part of the reason I got hired is because my mother worked here [at the school] for 28 years. I'm from here so I think my name ...., I was involved with the community because of my kids. That's what got me hired. I mean, I think that is a big thing. Mrs. Lynes indicated her mother was a primary source of encouragement to move into administration — she saw her daughter's potential. Another encourager was a fellow teacher at the technology center where she worked for 17 years.
She told Mrs. Lynes, "You're so smart” and "You're so good. I think you can do this."

In this small school, Mrs. Lynes was responsible for a wide variety of administrative and staff duties. After serving as morning hall monitor, Mrs. Lynes returned to the office that was noisy with morning conversations, phones ringing, and several students arriving late. She watched over the shoulder of a student who read the morning announcements over the intercom; she watched a computer monitor of a 5 X 5 grid of video surveillance of the school. In a few short minutes, Mrs. Lynes signed two field trip forms, wrote up nine tardy slips, agreed to call the manager of the local fast food restaurant to discuss why one student was working until 12:30 a.m., checked on a student who was injured in the previous nights' basketball game, and had a private conversation with the assistant superintendent. Mrs. Lynes seemed to be involved in every detail that occurred at the school during the day.

Case 3: Ester Wyckham, Edwards High

School. Mrs. Wyckham asked to meet in a superstore parking lot on her way to a counselors' meeting at a community college. Tall and thin with shoulder-length blonde hair and steel blue eyes, she appeared to be in her early 50s. Dressed in black pants and a short-waisted black and white tweed jacket with golf ball-sized black buttons, she carried an oversized Coach purse. She wore a gold watch and a large diamond ring on her left hand, a chunky gold and pearl bracelet on her right wrist, and matching pearl earrings. She greeted me with a lilt in her voice and laughed easily.

Mrs. Wyckham grew up in a university town; her mother was a teacher and her father a university professor. She explained that her husband was a local boy from her current school district; her three children were all graduates of Edwards High School. Her family owned a large farming business in the community. Mrs. Wyckham's chic accessories made it difficult to picture her driving a tractor; rather, visions of Green Acres flashed to mind.

Mrs. Wyckham taught at nearby schools, and was offered a position as a middle school principal but turned it down because she did not want to miss her children's extracurricular activities. She told the superintendent who tried to recruited her,

I'm not going to give up my family for this job. I want to be principal at some time in my life, but this just isn't the right time and the right opportunity for me. I just can't attend all the middle school activities and say my kids are important to me.

For Mrs. Wyckham, the principalship was "a goal and a dream early." She explained, "I knew what I wanted to do eventually. I taught for three years so 
when I was off those ten years [to raise her children] I just kept going to school. I thought, "I will get as many Masters Degrees as I can in this 10 years."

Mrs. Wyckham served on the school board for her community before being recruited by the superintendent to become the high school principal, counselor, athletic director, Title I and Title III coordinator, and bus driver "as needed." Mrs. Wyckham did all of her own secretarial work at the high school that employed 10 teachers and 20 support staff, and housed 77 students in grades 7-12. She commented that as a small-school principal, "There is nothing you don't do."

Case 4: Katie Fitzgerald, Parsons High

School. Parsons High School is a 5A school located in a community too large to be described as rural and too far from the nearest city to be classified as suburban. The state highways through town are lined with mom-and-pop shops rather than franchises. Mrs. Fitzgerald grew up in a small, consolidated school district just outside of the town where Parsons High School was located and taught at PHS for 19 years. Beyond retirement age, her shoulder-length blonde hair curled away from her tan face; she wore a quilted rose jacket with matching rose and silver jewelry, a gray skirt, gray hosiery, and gray tennis shoes. Mrs. Fitzgerald was a National Board Certified high school science teacher and coached the academic team, academic decathlon, and mock trials. Prior to her six years as principal, she served one year as an administrative intern and one year as an assistant principal.

At 7:15 a.m. the morning of her interview, Mrs. Katie Fitzgerald met with her two assistant principals and the director of the alternative school for 10 to 15 minutes. As the meeting came to a close, loud laughter could be heard. As the three male administrators exited her office, one jokingly said, "I enjoy these morning conversations. They are rejuvenating most times."

Mrs. Fitzgerald asked me to have a seat and then stepped into the outer office to make the morning announcements for approximately 700 high school students, 48 teachers, and 20 support staff. This was the only time she left her office during the visit. She explained that she visited with the two high school counselors every day-either they came to see her or she went to see them. After the announcements, she called a $12^{\text {th }}$ grade male aide to the office to give me a tour of the campus, thus limiting opportunities to observe how she interacted with the staff or students.

At the end of the tour, Mrs. Fitzgerald answered the formal interview questions, but offered no insight to her personal life. After the interview, she did not invite me to stay and observe or introduce me to any school employees. Mrs. Fitzgerald gave the impression that after 26 years in education, she was burned out. When she became principal six years previous, she was three years from retiring. She jokingly described her future as "day by day," but her voice was generally flat and her interview responses were more negative than those of the other participants. She explained, I have always told everybody on the board and my superintendent, “You don't have to write me up. You don't have to. Don't bother. All you have to do is just say, 'We are done with you' and I will retire. You will have my retirement papers in the next four hours if you want them.”

\section{Findings}

The analysis drew out what these women administrators expressed about the need for nurturing new administrators, particularly by male administrators; the investment they had in their communities and schools; and their experiences in transitioning from the classroom to administration. Standpoint theory indicates that perspectives from the lives of the less powerful can provide a more objective view than can perspectives from the lives of the more powerful. Although the four female principals in this case study differed in their methods for attaining their positions, three standpoints emerged as common themes. Each of the participants was nurtured through the process of transitioning from classroom teacher to administrator. In three of the cases, males in superior positions sponsored the participants into administration. All of the participants had a strong emotional investment in the schools and communities where they became principal. All of the principals experienced rites of passage as they attained the principalship.

\section{Standpoint 1: Nurtured}

The most predominant theme to emerge from the data was the standpoint that female principals have a support system, both personal and professional, that nurtured their transition from the classroom into administration. The nurturers were professional mentors, parents, co-workers, long-time friends, principals, and superintendents.

The data suggest male gatekeepers encouraged these participants to continue their educations, take the principal's test, and apply for positions. Mrs. Fitzgerald's gatekeeper was the most deliberate when he approached her and said, "The principal's testing is open, and I want you to go take it because I need a lady as an assistant principal, and I want it to be 
you.” Mrs. Fitzgerald's principal became the district superintendent, and they developed a mutual support system. She explained, "He is still pretty supportive when I am really upset, and vice versa. When he is really upset...he will call me...just so he can vent for a while.”

Dr. Richardson confessed she had no aspiration to become an administrator "for a really long time." She did not follow her mother's recommendation to get her doctorate and move into administration, but did follow the same advice from her male principal. Even with 10 years of assistant principal and principal experience in the district, she did not apply to be principal of Johnson High School because she had previously applied and was not hired. When the job was posted the second time, she thought the district had already given her a message that they did not see her in that position. She applied only after the position closed and the male personnel director called and encouraged her to apply.

Mrs. Wyckham reported a "full circle" of support: family, teachers, and superintendent. While working as a teacher, Mrs. Wyckham followed a male principal to a different district with the hope of becoming a principal when he became superintendent, but that did not occur. She was encouraged to apply for her current position by the district superintendent and speculated that she may have been the only person interviewed for the position.

Males dominated the top echelons of administration in the case study school districts. The largest district, location of Johnson High School, was the only district that had ever had a female superintendent. Mrs. Wyckham was the first female to serve on the school board in her district and was very candid about her responsibilities as the first female board member. She declared, "Females in ... smaller communities, they are very, very important and I think being an educator, and being a board member, really enlightened a lot of other board members." Mrs. Wyckham was the first female high school principal in her district, and Mrs. Lynes was the second in her district. Mrs. Fitzgerald reported her 5A school district had more female than male high school principals in the last 20 years, but never a female superintendent. Mrs. Lynes and Mrs. Wyckham continued to be supported by their male superintendent mentors who have encouraged them to take over their positions when they retire. Both superintendents invited Mrs. Lynes and Mrs. Wyckham to sit in on meetings to provide them with superintendent experience and kept them involved in school issues.

The need to nurture their children delayed Dr. Richardson, Mrs. Lynes, and Mrs. Wyckham in moving to administrative positions. All three cited sacrificing their goals to fulfill family commitments. Dr. Richardson remained a middle school principal while her three children were young because it had fewer evening activities than a high school position. Mrs. Wyckham taught for 3 years, then stayed at home 10 years to raise her children before returning to education. She also declined a principal's position because it would have caused her to miss her children's activities. Mrs. Lynes did not apply for an administrator's job until her sons were out of school.

In addition to being nurtured, this standpoint suggests unconventional recruitment practices on behalf of these school districts and a need for the female candidates to be encouraged before they would apply. With the exception of Mrs. Lynes, each study participant was asked to apply for her position and was hired. Mrs. Fitzgerald applied to be the district curriculum director without the support of her gatekeeper and was not hired. She reflected, "He had already made up his mind." Hoff and Mitchell (2008) asserted, "Women also waited for someone else to "tap" them for the role and encourage them to apply, clearly needing more affirmation before proceeding into administration than men did” (p. 7).

\section{Standpoint 2: Invested}

All four female principal's standpoint embraced their community involvement, their educational and work experiences, and their professional association memberships. They all expressed doubt about their job skills when they first moved into administration; however, compared to males in similar studies, they were more prepared in terms of years of classroom experience, advanced degrees, and lower-level administrative work.

All four principals grew up in the area where they currently worked as an administrator or had family in the area. Dr. Richardson and Mrs. Fitzgerald worked in their schools for more than a decade. Mrs. Wyckham served on the school board for eight years and her husband's family were prominent members of the community for several generations. Mrs. Lynes' children were fourthgeneration graduates of her school, and she worked for 17 years at a technology center that was a partner school. All four had children who attended school in their districts. These results are supported by Hoff and Mitchell's (2008) study that found men are more mobile when they search for an administrator's position. Her results indicated $66.5 \%$ of male participants had moved to assume an administrative job compared to $44.5 \%$ of women.

Mrs. Lynes noted a downside to being entrenched in the community and maintaining 
confidentiality. She was very candid about going to school with many of her student's parents and even some of her current teaching staff. She also knew her students' grandparents. She said, "The hardest part is when they [the community] hear something or know something .... and they want to talk to you about it and you can't."

Dr. Richardson, Mrs. Lynes, and Mrs. Wyckham credited educational experiences as helping them earn their current positions. These experiences included formal education, workshops by educational agencies, and workshops by professional organizations. Although all the principals held at least a master's degree, Dr. Richardson was the only principal with an advanced degree in school administration. Nonetheless, she expressed a lack of confidence when she moved into her first administrator position. She believed, "I was confident of what I could do cerebrally, but not experience wise.” Even though their advanced degrees were in education, Mrs. Fitzgerald and Mrs. Wyckham felt underprepared because their graduate degrees were not in school administration. Mrs. Wyckham supplemented her degree with an administrator development course provided by an educational agency, but revealed the learning curve was still bigger than she thought it would be. Mrs. Fitzgerald focused on her personal experiences rather than her formal education. She pointed out that her medical background, running for political office, and experiences as a teacher's union representative were key to her being hired into administration.

\section{Standpoint 3: Experienced rites of passage to principalship}

Mrs. Wyckham was the only study participant to move directly from the classroom into administration. Dr. Richardson spent 10 years in other administrative positions. Mrs. Lynes moved out of the classroom and was evening adult coordinator at her technology center as well as the junior high principal for four years at her school. Mrs. Fitzgerald was an administrative intern and assistant principal before becoming the high school principal. Hoff and Mitchell's (2008) research study revealed $61.14 \%$ of women compared to $5.21 \%$ of men waited until they met all of the educational requirements (certificate and advanced degrees) and for their children to be grown before entering administration. They concluded qualified women were being overlooked while men without certificates were being hired.

Each of the study participants indicated areas they felt self-confident about their move into administration. They cited their years of classroom work, extra duty assignments, or being a National Board Certified Teacher. Mrs. Fitzgerald, Dr. Richardson, and Mrs. Lynes gave examples of their performance tied to their own masculine images of leadership.

Although Mrs. Lynes had four years of junior high principal experience, she was still finding her way as a first-year high school principal. She spoke of female principals being perceived as being weak: "There is a lot of stigma about maybe that we're not as tough, maybe can't handle a lot of the extracurricular things that go on. And I think-well I know, I have done a good job at doing that or I would not have moved from the junior high to the high school. I think I had to prove myself there.”

\section{Discussion}

This study focused on Oklahoma participants; however, filling high school administration positions is a national concern. Comparison of the information in Tables 1 and 3 shows that Oklahoma (23\%) is behind the national average of female high school principals in public schools (30\%). This study confirms previous research (Glass, 2000; Hoff, 2006; 2008; Baxter 2009) that although women complete educational leadership programs at higher rates than do their male counterparts, moving from the classroom to the high school principalship is difficult. Barriers included family responsibilities, lack of confidence in formal education, and lack of mobility. Positive aspects included support by their family, coworkers, and administrators.

This study found that making a connection with a male in a superior leadership position was the most important employment factor. The participants had strong male mentors who served as sponsors in assisting their advancement, were highly vested in the communities in which they served, and followed a path appropriate for their successes. Their rites of passage included work experience in lower-level administrative positions, self-imposed notions of leadership, and finding their own female leadership style.

The Oklahoma female high school principals described their experiences of seeking and achieving employment as a principal in positive terms. The major factor that affected their advancement into administration was having a strong support system and network of community connections. Study participants were supported by their family and friends; all had mothers who worked in education and encouraged their daughters to advance into administration. Their mentors, who in many cases were male administrators, provided assistance and encouragement during the transition from classroom 
to administration. Standpoint 1 suggested female principal candidates were nurtured by their support system and encouraged to apply for administrator positions. Aspiring women principals will benefit by strengthening their support systems through networking or seeking out a sponsor, especially a sponsor in their target school district.

Accommodations for family responsibilities increased job preparedness. The participants purposefully waited until their children were grown before moving into administration. The additional years spent raising children allowed the participants the time to earn advanced degrees and gain additional years in the classroom. The participants in this study completed more than the state-required educational degrees and years of classroom teaching before moving into administration. The female candidates joined the job market more formally prepared than were their younger, male counterparts. Because the female principal candidates were not mobile, the additional years in the classroom increased the time invested in their school districts. The participants were all community insiders who progressed within their local school systems. Standpoint 2 proposed women were invested in their local school districts, their education, their work experience, and their professional association memberships. Aspiring women principals who postpone their careers for the sake of family can take advantage of the additional time by earning graduate degrees, joining professional organizations, and upgrading their administrative skills. The obvious negative aspect of delayed entry to administration is that women were older when searching for their first administrative position. One participant mentioned she was not hired for a principal's job because she was not bringing children with her to the school district and the younger, male candidate was bringing three children. Age discrimination could be a factor in a male-dominated career.

Accepting lower level administrative positions may be an essential starting point for aspiring female principals. Before becoming high school principals, the participants in this study served as administrative interns, assistant principals, middle school principals, junior high principals, and board members.

Participants believed starting at the bottom, continuing education, and professional involvement increased access to the high school principal position. Standpoint 3 identified that it was difficult to move directly from the classroom into the high school principal's job. Aspiring women principals may find advantage in willingness to serve in lower-level administrative position before stepping into the high school principal's office.

\section{Limitations}

This study addressed the experiences of four female principals in the state of Oklahoma and may not represent the experiences of all female principals. The findings of this study cannot be generalized to all female high school principals in Oklahoma or to principals in other states or geographical areas. However, the results reflecting the participants' experiences can contribute to the continuing discussion of gender equity in the principalship.

\section{Conclusion}

In practice, the barriers that have limited administrative opportunities for women—lack of mentors, lack of networking, and deficits in their knowledge base of school finance and operationscan be corrected. This research offers guidelines for females who are starting on the path to administration. These guidelines may assist the aspiring administrator in avoiding common pitfalls, provide inspirational comments from women who have been successful in breaking through the glass ceiling, and inform women considering a move to administration of key factors that may influence successful goal attainment. Results of the study may assist women in delineating their professional goals. Although existing laws support equity in the workplace, women who desire to enter high school administration must be prepared to navigate the cultural stigmas that still exist.

\section{References}

Baxter, K. J. (2009). Women in the high school principalship: A study of leadership at three schools. (Doctoral dissertation). Available from ProQuest Dissertations and Theses database. (AAT 3358888)

Bernstein, R. (2011, April 26). More working women than men have college degrees, census bureau reports. Retrieved from http://www.census.gov/newsroom/releases/arch ives/education/cb11-72.html

Bloomberg, L. D., \& Volpe, M. (2008). Completing your qualitative dissertation. Los Angeles, CA: Sage Publications, Inc.

Creswell, J. W. (2009) Research design: Qualitative, quantitative, and mixed methods approaches. Los Angeles, CA: Sage Publications, Inc. 
Digest of education statistics. (2007). National center for education statistics. Washington, D.C.: U.S. Department of Education. Retrieved November 21,

2009. http://nces.ed.gov/programs/coe/2007/sec tion4/ indicator34.asp.

Eckman, E. W. (2004). Does gender make a difference? Voices of male and female high school principals. Planning and Changing, 35(3/4), 192-209.

Gilmour, S. L., \& Kinsella, M. P. (2009). Succeeding as a female superintendent: How to get there and stay there. Lanham, MD: Rowman \& Littlefield.

Glass, T. E. (2000). Where are all the women superintendents? School Administrator. Retrieved from http://findarticles.com/p/articles/mi_M0JS D/is_6_57/ai_77336323/

Guramatunhu-Mudiwa, P. (2015). The gender shift in enrollment patterns in higher education: A case study of a school administration program. Advancing Women in Leadership, 35 (1), 120133.

Harding, S. (2001). Feminist standpoint epistemology (pp. 145-168). In M. Lederman and I. Bartsch (Eds.), The gender and science reader. New York, NY: Routledge.

Hoff, D. L., Menard C., \& Tuell, J. (2006). Where are the women in school administration? Issues of access, acculturation, advancement, advocacy. Journal of Women in Educational Leadership, 4(1), 53-60.

Hoff, D. L., \& Mitchell, S. N. (2008, April). In search of leaders: Gender factors in school administration. Advancing Women in Leadership. Retrieved from http://advancingwomen.com/awl

Keiper, L. (2011, August 17). Survey: Women get more value out of college than men do. Reuters. Retrieved from
http://www.reuters.com/assets/print?aid=USTR E77G4CI20110817

Marklein, M. B. (2005, October 19). College gender gap widens: $57 \%$ are women. USA Today.

Retrieved from http://www.usatoday.com/news/education/2005 -10-19-male-college-cover_x.htm

Narayan, U. (1989): "The Project of Feminist Epistemology" in S. Bordo and A. Jaggar eds., Gender/Body/Knowledge: Feminist

Reconstructions of Being and Knowing

(Rutgers: Rutgers University Press) pp.256-272.

Oklahoma Secondary Schools Athletic Association. Retrieved February 24, 2012 from http://www.ossaa.net/docs/policiesRules/1112 Constitution.pdf

Oklahoma State Department of Education open records request, November, 2010.

Roser, V., Brown, M., \& Kelsey, C. (2009). Principal gender as related to campus size, level, and academic rating. Advancing Women in Leadership, 29(10), 1-14.

Sommers, C.H. (2008, March/April). Why can’t a woman be more like a man? The American: The Journal of the American Enterprise Institute. Retrieved from http://www.american.com/archive/2008/m arch-april-magazine-contents/why-can2019t-awoman-be-more-like-a-man

Wood, J. T. (1993). Gender and moral voice: Moving from women's nature to standpoint epistemology. In Women's Studies in Communication. Retrieved October 22, 2011, from http://users.ipfw.edu/lakes/Standpoint\%20 Theory.

\section{About the authors:}

Dr. Kruse is a former high school and adult business teacher. She is a licensed principal and superintendent with a M.Ed. in Adult Education and an Ed.D. in School Administration. Dr. Kruse currently serves as Dean of Academic Services at a rural community college.

Bernita L. Krumm, Ph.D., is a former P-12 teacher, counselor, department chair, and school board member. An emeritus faculty member of the College of Education at Oklahoma State University, Stillwater, Oklahoma, Dr. Krumm's research focuses on leadership and gender in education, school/community collaboration, and American Indian education. Email: Bernita.krumm@okstate.edu 